\title{
MUHASEBE MESLEK MENSUPLARINDA STRESE NEDEN OLAN FAKTÖRLER ÜZERİNE BİR ARAȘTIRMA: KAYSERİ İLİ ÖRNEĞİ*
}

\author{
Doç. Dr. Semra AKSOYLU**
}

Araştırma Makalesi / Research Article

Muhasebe Bilim

Dünyası Dergisi

Mart 2019; 21(1);228-245

\section{ÖZ}

$\mathrm{Bu}$ çalışmanın temel amacı muhasebe meslek mensuplarını etkileyen temel mesleki stres faktörlerini ortaya koymaktır. Ayrıca meslek mensuplarının mesleki stres faktörlerinden etkilenme durumlarının demografik değişkenlere göre farklılık gösterip göstermediği araştırılmıştır. Çalışma kapsamında Kayseri ilinde çalışan muhasebe meslek mensuplarına 2 bölümden oluşan anket uygulanmıştır. Elde edilen bulgular 1şı̆̆ında mesleki strese neden olan; fiziki koşullar, maddi kaygılar, standartlar ve denetim, zaman, işin niteliği, mesleğin devamlılığı, bilgi düzeyi ve etik olmak üzere 8 faktör belirlenmiştir. Belirlen faktörlerle medeni durum, eğitim durumu, çalışma şekli, mesleki tecrübe ve gelir düzeyi demografik değişkenleri arasında istatistiki açıdan anlamlı ilişki tespit edilmiştir.

Anahtar Kelimeler: Mesleki Stres, Muhasebe Meslek Mensubu, Kayseri

JEL Sınıflandırması: M40, M41

AN INVESTIGATION ON THE FACTORS OF STRESS IN ACCOUNTING PROFESSIONALS: THE CASE KAYSERI PROVINCE

\section{ABSTRACT}

The main purpose of this study is to reveal the basic occupational stress factors affecting the professional accountants. In addition, it has been investigated whether the effect of the occupational stress factors on the professionals differ according to the demographic variables. In the scope of the study, a survey consisting of 2 chapters was applied to accounting professionals working in Kayseri. According to the findings, 8 factors that cause occupational stress were determined. These are: physical conditions, material concerns, standards and supervision, time, nature of work, continuity of profession, level of knowledge and ethics. Statistically significant relationships were found between these factors and the demographic variables of the marital status, educational status, working style, occupational experience and income level.

Keywords: Occupational Stress, Accounting Professional, Kayseri Province

JEL Classification: M40, M41

\footnotetext{
${ }^{*}$ Makale gönderim tarihi: 16.10.2018, kabul tarihi: 28.12.2018.

** Kayseri Üniversitesi, Uygulamalı Bilimler Fakültesi, Muhasebe ve Finans Yönetimi Bölümü, aksoylus@erciyes.edu.tr, orcid.org/0000-0002-5837-1600

Atıf: Aksoylu, S. (2019). Muhasebe meslek mensuplarında strese neden olan faktörler üzerine bir araştırma: Kayseri ili örneği. Muhasebe Bilim Dünyası Dergisi, 21(1), 228-245. http://dx.doi.org/10.31460/mbdd.471268.
} 


\section{GİRIŞ̧}

Günümüzde hem sosyal hayattaki, hem de meslek hayatındaki olağan ve olağandış1 pek çok iş, bireyleri az ya da çok stresle karşı karşıya bırakmaktadır. Bu durum bireylerin stresten uzak kalma ihtimalini neredeyse ortadan kaldırmıştır. Gündelik hayatta kullandığımız anlamıyla stresi ilk tanımlayan kişi Kanadalı fizyoloji bilgini Dr. Hans Selye'dir. Selye yürüttüğü çalışmalar neticesinde 1950 yılında "Stres" isimli bir eser yayımlamış ve bu eserde stresi, hem iç hem dış ortamdan kaynaklanan etkenlerin organizmada ortaya çıkardığı değişiklik olarak tanımlamıştır (Gümüştekin ve Öztemiz 2004, 64). Yoğun iş hayatında karşılaşılan stres çalışanlar açısından olduğu gibi, yöneticiler açısından da önemli sonuçlar ortaya çıkarabilmektedir. Stres nedeniyle ortaya çıkan bu sonuçlar bireysel veya örgütsel açıdan ele alınabilir. Uzun süre devam eden stres, bireyi hem fiziksel hem de psikolojik olarak olumsuz yönde etkiler. Bu durum beraberinde, çalışanın sağlığının zarar görmesi ve çalışanın örgüte sağladığı katkının ciddi ölçüde azalması sonucunu doğurur. Bilim insanlarının yaptıkları çeşitli araştırmalar stresin, çalışanları işe devamsızlık yapmaya yönelttiğini hatta durumun işten ayrılma ile sonuçlanabildiğini göstermiştir. Yani stres hem çalışan hem de işyeri açısından telafisi mümkün olmayan sonuçlar ortaya çıkarabilmektedir. Çalışan bireylerden herhangi birinde ortaya çıkan stres, bireyin çevresindeki diğer çalışanları da etkileyebilmekte ve verimlilik giderek azalabilmektedir. Diğer taraftan, strese neden olan etmenlerin ortadan kaldırılması yoluyla; çalışanın bireysel sağlığının korunması, çalışanın iş tatmininin yükseltilmesi ve içinde bulunduğu örgüte katkısının artırılması sağlanmaktadır (Bekçi ve diğerleri 2007, 146)

Muhasebe meslek mensubu kavramı kapsam itibariyle; herhangi bir kuruluşta çalışan muhasebe elemanlarından, mesleğin belki de en üst noktası olarak adlandırılabilecek yeminli mali müşavirlere kadar muhasebe alanında çalışan pek çok bireyi içine alan oldukça geniş bir kavramdır. Bu nedenle muhasebe mesleği, iş hayatında oldukça geniş bir kitleyi ilgilendiren meslekler arasında yer almaktadır. Muhasebe meslek mensupları da diğer mesleklere mensup bireyler gibi iş hayatının kaçınılmaz bir parçası olan stres ile sıklıkla mücadele etmektedirler. İş yoğunluğunun fazla olması, hazırlanan mali tabloların detaylı ve titiz bir çalışma gerektirmesi gibi pek çok etken meslek mensuplarının faaliyetlerini stres altında sürdürmelerine neden olmaktadır. Ülkemizdeki şartlar göz önünde bulundurulduğunda, bireylerin çalışma koşullarını zorlaştıran pek çok faktör olduğu düşüncesinin yerinde bir çıkarım olduğu söylenebilir. Bu çalışmanın temel amacı; muhasebe mesleğine mensup bireylerin iş hayatı boyunca karşılaştıkları ve strese neden olan faktörlerin ortaya konulmasıdır. Ayrıca strese neden olan faktörlerin çeşitli demografik değişkelere göre farklılık gösterip göstermediği de ele alınmaktadır. 


\section{STRESIN KAYNAKLARI VE SONUÇLARI}

Bireylerin günlük hayatta karşılaştığı pek çok durum ve yaşadığ 1 pek çok olay birer stres kaynağ1 olabilmektedir. Ayrıca bireylerin bu süreçte üstlendiği roller de potansiyel stres kaynağı olarak değerlendirilmektedir. Diğer bir ifadeyle, bireyin aile veya iş ortamında üstlenmiş olduğu roller ve bu roller arasında çıkabilecek çatışmalar strese yol açabilmektedir. Genel olarak stresin kaynağını oluşturan faktörler; bireysel, çevresel ve örgütsel faktörler olmak üzere üç ana başlık altında sinıflandırılmaktadır (Yanık 2017, 100).

Bireylerde görülen stresin yoğunluğu, örgüt içi ve dışı faktörlerin nitelikleriyle ilişkili olmanın yanı sıra bireylerin demografik ve kişilik özellikleriyle de yakından ilişkilidir (Gök 2009, 435). Cinsiyet, yaşam tarzı, aile, zaman baskısı, kişilik vb. strese neden olan alt faktörler, başlıca bireysel stres faktörlerinin kaynağını oluşturmaktadır (Kaya ve Kaya 2007, 44). Bir işyerinde çalışanların yaşamış olduğu stres, bahsi geçen bireysel nedenlerden kaynaklanıyorsa, yöneticilerin sağlayacağı destek sayesinde söz konusu bireysel sorunların işe yapacağı olumsuz etkinin önüne geçilebilmektedir. İşyerinde sosyal desteğe yönelik hizmet sunulması sorunun çözümü konusunda etkili olmaktadır. Böyle bir hizmetin sunulmadığı işyerlerinde ise işletme dışı kuruluşlardan destek alınması gerekmektedir.

Çevresel faktörler, çalışan bireylerin gün içerisinde karşı karşıya kaldıkları toplumsal ve teknolojik değişimler, ekonomik koşullar, yaşanılan şehrin genel problemleri, politik gelişmeler ve doğal felaketlerden oluşmaktadır (Tepeli ve diğerleri 2014, 743).

Örgütsel faktörlere gelindiğinde ilk karşımıza çıkan faktörler kariyer ve değerlendirme sorunlarıdır. İşletmelerde değerlendirmenin gerçekçiliği konusunda şüphelerin olması, başarı değerleme standartlarının uygun olmaması, yetersiz ve hizlı terfiler, terfilerde sergilenen sübjektif tutumlar, başarı arzusunun engellenmesi, çalışanların değerlendirme sistemine duyduğu inancın kaybolması gibi durumlar stres kaynağı olabilmektedir. Ayrıca işletmedeki hiyerarşik yapı, örgütsel iklim, iletişim eksikliği ve ast-üst ilişkisi de strese neden olan örgütsel faktörler arasında yer almaktadır (Kayıhan ve diğerleri 2015, 376). Çalışanların yaşadığı stresin örgütsel faktörlerden kaynaklandığı durumlarda, yöneticilerin destekleyici tutum sergilemeleri, stres yaşayan çalışanın iş tatminine ve işe devamına olumlu katkı sunmaktadır.

Bireyler hayatı boyunca örgütsel yani iş kaynaklı stres faktörlerinin yanı sıra bireysel ve çevresel pek çok stres faktörü ile karşı karşıya kalmaktadır. Genellikle bireylerin strese eğilimli olma düzeyleri birbirlerinden farkl1lık göstermektedir (Aş1k 2005, 11). Yani mesleki strese neden olan bu faktörler her birey açısından farklı önem arz etmekte ve farklı düzeyde strese neden olmaktadır. Yaşanan bu stres hem birey açısından hem de örgüt açısından çeşitli sonuçlar ortaya çıkarmaktadır. Stres kaynaklarının hem bireyler hem de örgütler üzerindeki olumsuz sonuçları Tablo 1'de verilmiştir. 
Tablo 1. Stresin Bireyler ve Örgütler Üzerindeki Olumsuz Sonuçları

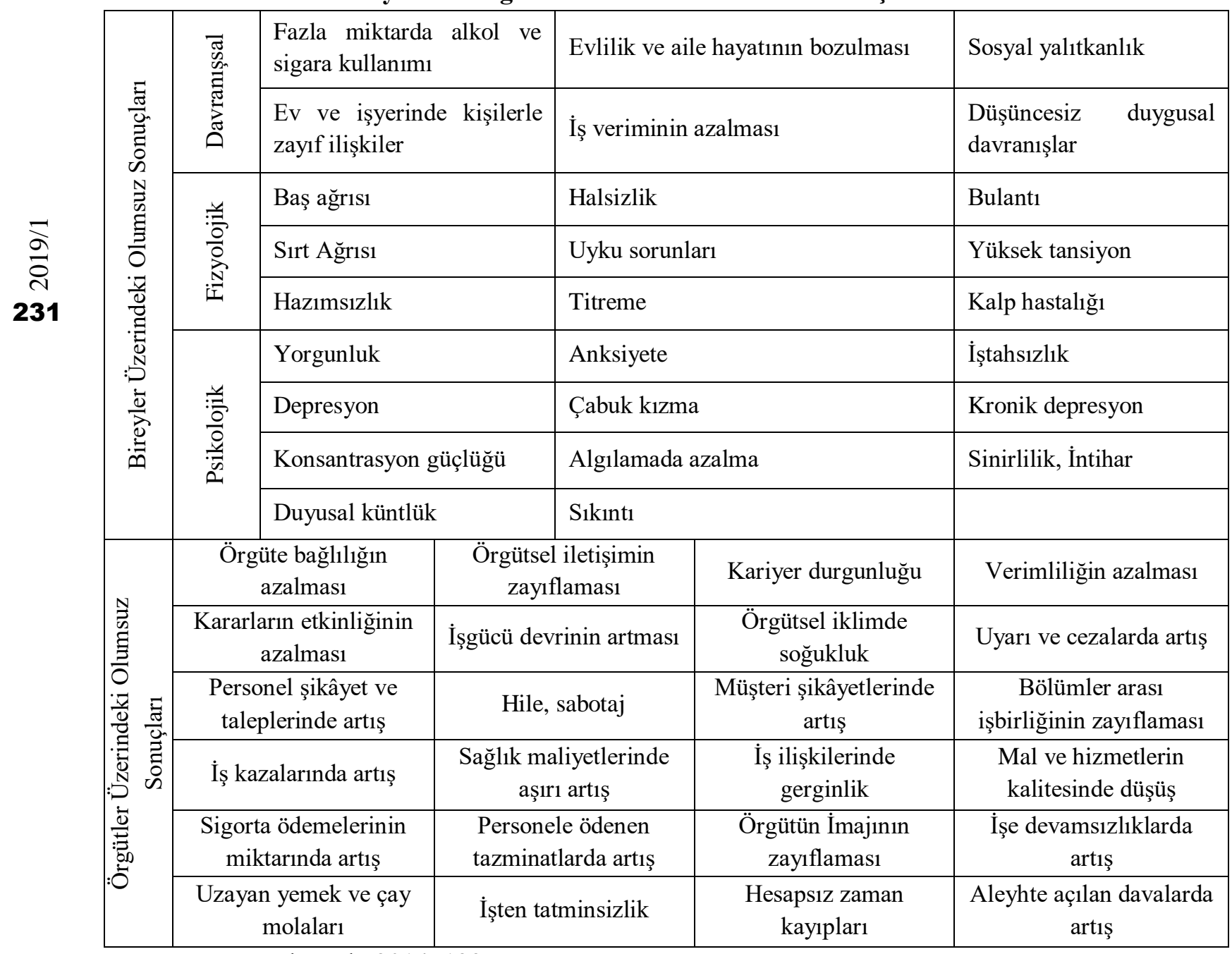

Kaynak: Kaplanoğlu 2014, 133.

\section{LITERATÜR}

Literatür incelendiğinde, muhasebe meslek mensuplarının iş hayatı boyunca karşılaştıkları strese neden olan faktörleri ele alan çok sayıda çalışma yapıldığı gözlenmektedir.

Kelly ve Barrett (2011) çalışmalarında, İrlandalı stajyer muhasebecilerin yaşadıkları mesleki stresin temel nedenlerini ve söz konusu stajyerlerin mesleki stres, iş tatmini ve işten ayrılma eğilimleri arasındaki ilişkiyi incelemişlerdir. Bulgular; sınav baskısının, rol çatışmasının, rol belirsizliğinin, nitelik ve nicelik olarak aşırı rol yükünün ve baskın karakterli yöneticinin aday meslek mensuplarının karşılaştığı en yaygın mesleki stres kaynakları olduğunu ortaya koymuştur.

Zeytin ve Gökgöz (2011) muhasebe mesleğini sürdüren muhasebe meslek mensuplarında strese neden olan faktörlerin ağırlık derecesini belirlenmek amacıyla Bilecik ve Yalova illerinde bir çalışma 
gerçekleştirmişlerdir. Yapılan analiz sonucunda; meslek mensuplarında strese neden olan faktörlerin 3 grup altında toplandığını ortaya koymuşlardır. Bu faktörler; iş yükünün fazlalığı, mevzuatın sıklıkla değişmesi ile gece gündüz çalışma zorunluluğu, tahsilâtların zamanında yapılamaması ve meslektaşların daha ucuza defter tutmasıdır.

Shin ve Lee (2015) muhasebecilerin duygusal emek, mesleki stres ve mesleki tükenmişlikleri arasındaki ilişkileri incelemek amacıyla yürüttükleri çalışmalarında, duygusal dışavurum sıklığının mesleki stres üzerinde olumsuz bir etkiye sahip olduğu ancak duygusal uyumsuzluğun mesleki stres ile istatistiksel olarak ilişkili olmadığı sonucuna ulaşmışlardır.

Yousefi ve diğerleri (2015) yapmış oldukları araştırmalarında, muhasebecilerin karşılaştıkları mesleki stres ile iş tatminleri arasındaki ilişkiyi incelemeyi amaçlamışlardır. Elde ettikleri veriler mesleki stresin iş tatmini üzerinde önemli ve olumsuz bir etkiye sahip olduğunu, performans değerlendirmesinin ve iş yükünün ise iş tatmini üzerinde anlamlı bir etkisi olmadığını göstermiştir.

Bulgurcu ve Gürel (2016) işe bağlllık, duygusal tükenmişlik ve iş stresi düzeylerinin iş-aile çatışması düzeyi üzerindeki etkilerini incelenmek amacıyla Denizli ilinde serbest olarak çalşsan muhasebe meslek mensupları üzerine bir araştırma yürütmüşler. Araştırma kapsamında elde edilen veriler, duygusal tükenmişlik ve iş stresi ile iş-aile çatışması arasında pozitif, işe bağlılık ve iş-aile çatışması arasında ise negatif bir ilişki olduğunu ortaya çıkarmıştır.

Özmutaf ve Mizrahi (2017) serbest muhasebeci mali müşavirler ve diğer muhasebe çalışanları kapsamında iş stresinin iş performansına etkisinin belirlenmesi amacıyla İzmir ilinde yapmış oldukları çalışma ile muhasebe çalışanlarının mesleki yaşamlarında yüksek stres algısına sahip oldukları ve yöneticilerin konuya gereken önemi vererek çalışanların performanslarını iyileştirebilecekleri sonucuna ulaşmışlardır.

Güney ve Akdağ (2018) muhasebe meslek mensuplarının tükenmişlik düzeyleri üzerine Erzincan ve Erzurum illerinde yürüttükleri araştırmalarında, Erzurum'daki meslek mensuplarının tükenmişlik algılarının Erzincan'dakilere göre daha yüksek olduğunu tespit etmişlerdir. Ayrıca kadınların da erkeklere kıyasla tükenmişlik düzeylerinin yüksek olduğu sonucuna ulaşmışlardır.

\section{METODOLOJI}

Çalışmanın temel amacı; Kayseri' deki muhasebe meslek mensuplarında strese neden olan mesleki faktörleri açıklayabilmek ve bu faktörlerin demografik değişkenlere göre farklılık gösterip göstermediğini ortaya koymaktır. 
$\mathrm{Bu}$ amaç doğrultusunda 2 bölümden oluşan anket formu hazırlanmıştır. Anket formunun birinci bölümü muhasebe meslek mensuplarının demografik özelliklerini belirlemeye yönelik sorulardan oluşmaktadır. Meslek mensuplarının strese neden olan mesleki faktörlere yönelik görüşlerini ölçmeyi hedefleyen ikinci bölümün hazırlanmasında; Tepeli, Heybeli ve Kayıhan (2014) çalışmalarından faydalanılmıştır. İkinci bölümdeki stres kaynaklarını belirlemeye yönelik önermelere verilecek cevaplar için 5'li Likert ölçeği kullanılmıştır. Söz konusu ölçekte; önermelerin strese neden olma dereceleri (1) Hiç, (2) Az, (3) Orta, (4) Yüksek ve (5) Çok Yüksek ifadelerinden oluşmaktadır.

Anakütledeki büyüklüğünün bilinmesi durumunda geçerli örneklem hacminin belirlenmesi için

$$
n=\frac{N t^{2} p q}{d^{2}(N-1)+t^{2} p q}
$$

formülü kullanılmıştır (Cengiz ve Özden 2002, 71). Bu formülde kullanılan değişkenler;

n: örneklem büyüklüğü

N: anakütle büyüklüğü

p: incelenen olayın gerçekleşme olasılı̆̆

q: (1-p),

t: belirlenen anlamlılık düzeyi için $\mathrm{t}$ tablosundan bulunan değer ve

d: olayın görülme sıklığına göre kabul edilen örnekleme hatasını belirtmektedir.

Kayseri Serbest Muhasebeci Mali Müşavirler Odası 2017 yılı faaliyet raporuna ${ }^{1}$ göre Kayseri'de odaya kayıtlı 1447 meslek mensubu bulunmaktadır. Odadan edinilen bilgiye göre kayıtlı meslek mensuplarının bir kısmı fiilen çalışmamaktadırlar. Çalışma kapsamında fiilen çalışanlardan 255 tanesine ulaşılmıştır. Bu sayı belirlenen örnekleme hatası için yeterli olmaktadır. Meslek mensuplarına yüz yüze görüşme yöntemiyle anket uygulanmıştır.

Katılımcılara yöneltilen 34 önermenin analizlerde değişken olarak kullanılması yerine bu değişkenler faktör analizi yardımı ile 8 faktöre indirgenmiş ve demografik özelliklerin stres kaynakları ile ilişkisi bu faktörler üzerinden test edilmiştir.

\section{BULGULAR}

Çalışmanın bu bölümünde; katılımcıların, anketin birinci kısmında yer alan demografik özelliklerle ilgili sorulara ve anketin ikinci kısmında yer alan mesleki stres faktörlerini ölçmeye yönelik önermelere vermiş oldukları cevapların neticesinde ortaya çıkan istatistiksel veriler bulunmaktadır.

\footnotetext{
${ }^{1}$ http://www.ksmmmo.org/yini/faaliyet/2017_Kayseri_SMMM_Odasi_Faaliyet_Raporu.pdf
} 


\subsection{Demografik Bulgular}

Araştırmaya katılan 255 meslek mensubuna ait demografik bulgular Tablo 2'de görülmektedir.

Tablo 2. Demografik Bulgular

\begin{tabular}{|c|c|c|c|c|}
\hline Değişken Kodu & & Demografik Özellikler & $\mathbf{f}$ & $\%$ \\
\hline \multirow{2}{*}{ D1 } & \multirow{2}{*}{ Cinsiyet } & Kadın & 53 & 20,8 \\
\hline & & Erkek & 202 & 79,2 \\
\hline \multirow{2}{*}{ D2 } & \multirow{2}{*}{$\begin{array}{l}\text { Medeni } \\
\text { Durum }\end{array}$} & Evli & 187 & 73,3 \\
\hline & & Bekâr & 68 & 26,7 \\
\hline \multirow{5}{*}{ D3 } & \multirow{5}{*}{ Yaş } & 25 ve alt1 & 12 & 4,7 \\
\hline & & $26-35$ & 132 & 51,8 \\
\hline & & $36-45$ & 77 & 30,2 \\
\hline & & $46-55$ & 21 & 8,2 \\
\hline & & 56 ve üzeri & 13 & 5,1 \\
\hline \multirow{4}{*}{ D4 } & \multirow{4}{*}{$\begin{array}{l}\text { Eğitim } \\
\text { Durumu }\end{array}$} & Lise & 6 & 2,4 \\
\hline & & Önlisans & 16 & 6,3 \\
\hline & & Lisans & 217 & 85,1 \\
\hline & & Lisansüstü & 16 & 6,3 \\
\hline \multirow{3}{*}{ D5 } & \multirow{3}{*}{$\begin{array}{l}\text { Mesleki } \\
\text { Unvan }\end{array}$} & SM & 11 & 4,3 \\
\hline & & SMMM & 244 & 95,7 \\
\hline & & YMM & 0 & 0 \\
\hline \multirow{3}{*}{ D6 } & \multirow{3}{*}{$\begin{array}{c}\text { Çalışma } \\
\text { Şekli }\end{array}$} & Bağımsız & 137 & 53,7 \\
\hline & & Kamu / Özel Firmaya Bağl1 & 36 & 14,1 \\
\hline & & Muhasebeci / Mali Müşavir Yanında & 82 & 32,2 \\
\hline \multirow{5}{*}{ D7 } & \multirow{5}{*}{$\begin{array}{l}\text { Mesleki } \\
\text { Tecrübe }\end{array}$} & 7 y1l ve alt1 & 70 & 27,5 \\
\hline & & $8-15$ aras1 & 94 & 36,9 \\
\hline & & $16-23$ aras 1 & 49 & 19,2 \\
\hline & & $24-31$ aras 1 & 28 & 11 \\
\hline & & 32 yıl ve üstü & 14 & 5,5 \\
\hline \multirow{6}{*}{ D8 } & \multirow{6}{*}{$\begin{array}{c}\text { Yaklaşı1k } \\
\text { Aylık } \\
\text { Gelir (£) }\end{array}$} & 1.500 ve alt 1 & 25 & 9,8 \\
\hline & & $1.501-2.500$ aras1 & 68 & 26,7 \\
\hline & & $2.501-3.500$ aras1 & 58 & 22,7 \\
\hline & & $3.501-4.500$ aras1 & 30 & 11,8 \\
\hline & & $4.501-5.500$ aras1 & 19 & 7,5 \\
\hline & & 5.501 ve üzeri & 55 & 21,6 \\
\hline
\end{tabular}

\subsection{Faktör Analizi ve Bulguları}

Faktör analizi genellikle araştırmalarda kullanılan çok sayıdaki değişkenin aslında birkaç temel değişkenle ifade edilip edilemeyeceğini araştırmaktadır. Faktör analizinin iki temel amacı vardır. Bunlar; boyut indirgemek ve değişkenler arasındaki ilişkilerdeki yapıyı araştırmak yani değişkenleri siniflandirmaktır (Alpar 2017, 245).

Analizin ilk aşaması veri setinin faktör analizine uygunluğunun test edilmesidir. Bunun için Barlett testi ve Kaiser - Meyer - Olkin (KMO) testlerinden faydalanılır (Kalayc1 2014, 322). Faktör analizinde, değişkenler arasında korelasyonların 0,3 - 0,9 arasında olması istenir (Alpar 2017, 265). Bu 
aralıklarda olmayan korelasyon katsayılarının fazlalığı, veri setinin faktör analizi için uygun olmadığını gösterir. $\mathrm{Bu}$ nedenle en azından bazı değişkenler arasında anlamlı bir korelasyonun varlığını ve verilerin faktör analizine uygunluğunu belirleyebilmek amacıyla Barlett ve KMO testlerini uygulanmıştır. KMO indeksi 0 ile 1 arasında bir değer alır ve 0,5 'ten büyük çıkması verilerin faktör analizi için uygun olduğunu gösterir (Williams ve diğerleri 2010, 5).

Test sonuçları Tablo 3'de görülmektedir.

Tablo 3.KMO ve Barlett Testi

\begin{tabular}{|lc|r|}
\hline \multicolumn{2}{|l|}{ KMO Örneklem Yeterlilik Testi } &, 854 \\
\hline Barlett'sTesti & Ki-Kare & 4191,422 \\
& $\mathrm{p}$ &, 000 \\
\hline
\end{tabular}

KMO test sonucunun 0,854 çıkması yukarıda da belirtildiği gibi araştırma verilerinin ve örneklemin yeterli olduğunu, Barlett testi anlamlılığının 0,000 olması $(p<0,05)$ verilerden anlamlı faktörler elde edilebileceğini göstermektedir.

Faktörlerin belirlenmesinde Kaiser Kriteri (özdeğer $>1$ ), Scree testi, paralel analizler ve varyansların kümülatif yüzdesi gibi birçok yöntem kullanılabilir (Williams ve diğerleri 2010, 6). Çalışmamızda özdeğer istatistiklerinden faydalanılmıştır. Faktörlerin özdeğerlerinin 1'den büyük olması önemli olarak nitelendirilebilmeleri için yeterlidir (Kaiser 1960, 145).

Özdeğer (Eigenvalue) istatistikleri ve faktörlerin açıklayabildikleri varyans yüzdeleri ile ilgili bilgiler Tablo 4'te görülmektedir.

Tablo 4. Açıklanan Toplam Varyans

\begin{tabular}{|c|c|c|c|c|c|c|c|c|c|}
\hline \multirow{2}{*}{ Components } & \multicolumn{3}{|c|}{ Initial Eigenvalues } & \multicolumn{3}{c|}{$\begin{array}{c}\text { Extraction Sums of Squared } \\
\text { Loadings }\end{array}$} & \multicolumn{3}{c|}{$\begin{array}{c}\text { Rotation Sums of Squared } \\
\text { Loadings }\end{array}$} \\
\cline { 2 - 11 } & Total & $\begin{array}{c}\text { \% of } \\
\text { Variance }\end{array}$ & $\begin{array}{c}\text { Cumulative } \\
\text { \% }\end{array}$ & Total & $\begin{array}{c}\text { \% of } \\
\text { Variance }\end{array}$ & $\begin{array}{c}\text { Cumulative } \\
\text { \% }\end{array}$ & Total & $\begin{array}{c}\text { \% of } \\
\text { Variance }\end{array}$ & $\begin{array}{c}\text { Cumulative } \\
\text { \% }\end{array}$ \\
\hline 1 & 10,440 & 30,705 & 30,705 & 10,440 & 30,705 & 30,705 & 3,367 & 9,903 & 9,903 \\
\hline 2 & 2,419 & 7,114 & 37,819 & 2,419 & 7,114 & 37,819 & 3,226 & 9,489 & 19,392 \\
\hline 3 & 1,736 & 5,105 & 42,924 & 1,736 & 5,105 & 42,924 & 3,041 & 8,943 & 28,335 \\
\hline 4 & 1,647 & 4,846 & 47,770 & 1,647 & 4,846 & 47,770 & 2,971 & 8,737 & 37,072 \\
\hline 5 & 1,480 & 4,352 & 52,122 & 1,480 & 4,352 & 52,122 & 2,702 & 7,946 & 45,019 \\
\hline 6 & 1,409 & 4,145 & 56,267 & 1,409 & 4,145 & 56,267 & 2,277 & 6,697 & 51,716 \\
\hline 7 & 1,246 & 3,665 & 59,933 & 1,246 & 3,665 & 59,933 & 2,150 & 6,324 & 58,040 \\
\hline 8 & 1,081 & 3,180 & 63,112 & 1,081 & 3,180 & 63,112 & 1,724 & 5,072 & 63,112 \\
\hline 9 &, 974 & 2,865 & 65,978 & - & - & - & - & - & - \\
\hline
\end{tabular}

Başlangıç özdeğer toplamları 1'in altına düştüğü için 10. bileşenden sonra tabloda yer almamıştır. Tablo 4 incelendiğinde özdeğer istatistiği 1'den büyük olan 8 faktör söz konusudur. Birinci faktör 
toplam varyansın \%9,903'ünü, birinci ve ikinci faktörler birlikte toplam varyansın \%19,392'sini açıklamaktadır. İlk 8 faktör ise toplam varyansın \%63,112'sini açıklamaktadır.

Daha sonraki işlem değişkenlerin faktörlere atanmasıdır. Bunun için orijinal değişken ile faktörler arasındaki korelasyonlar hesaplanır. Bir değişkenin faktörlerle arasındaki mutlak değerce en yüksek olan korelasyon katsayısı dikkate alınarak atama yapılır (Kalaycı 2014, 330). Bir faktör, kendisine en az iki değişken atandığ zaman anlamlı hale gelir, aksi takdirde faktörün gözlemlenen değişkenden farkı kalmayacaktır (Henson ve Roberts 2006, 408). Sonuç olarak faktörler ve faktörlere atanan değişkenler (ölçekteki sorular) Tablo 5’te görülmektedir.

Tablo 5. Faktörler ve Atanan Değisşenler

\begin{tabular}{|c|c|c|}
\hline Faktörler & Önermeler & $\begin{array}{l}\text { Faktör } \\
\text { Yükleri }\end{array}$ \\
\hline \multirow{7}{*}{$\begin{array}{l}\text { 1: Fiziki } \\
\text { Koşullar }\end{array}$} & Kullanılan araç-gereç ve donanımın yetersizliği & ,762 \\
\hline & İşyerinin fiziki koşullarının yetersizliği & ,708 \\
\hline & Mükellefin işyerine ulaşma zorluğu & 649 \\
\hline & İsle ilgili resmi kurumların çokluğu ve bu kurumların iş yerine uzaklı̆̆ı & ,577 \\
\hline & İnternet ve bilgisayar sistemindeki arızalar & ,470 \\
\hline & Mükellefin haksız talepleri & ,453 \\
\hline & Yapılan iş ile kişilik arasındaki uyumsuzluk & ,440 \\
\hline \multirow{7}{*}{$\begin{array}{l}\text { 2: Maddi } \\
\text { Kaygilar }\end{array}$} & Mükellefin muhasebe ücretini zamanında ödememesi & ,673 \\
\hline & Meslektaşların daha ucuza defter tutması & 672 \\
\hline & Mükellefler ile iletişimden kaynaklanan sorunlar &, 544 \\
\hline & Resmi dairelerin muhasebe meslek mensuplarına karşı tutumları & ,528 \\
\hline & Mükellefini kaybetme korkusu & ,501 \\
\hline & Meslek mensupları arasındaki rekabet & ,494 \\
\hline & Mesleğin geleceği ile ilgili endişeler & ,412 \\
\hline \multirow{3}{*}{$\begin{array}{l}\text { 3:Standartlar } \\
\text { ve Denetim }\end{array}$} & Denetim alanında getirilen yenilikler & ,777 \\
\hline & Muhasebe standartlarının zorunlu uygulanmasından kaynaklanan zorluklar & ,679 \\
\hline & İlgili kurumların veri tabanındaki aksaklıklar (internet vergi dairesi, SGK vb.) & ,506 \\
\hline \multirow{5}{*}{ 4: Zaman } & Uzun ve yorucu çalışma süreleri & ,791 \\
\hline & Aile ve sosyal hayata yeterli zaman ayıramama & ,787 \\
\hline & İş yükünün fazlalığı & ,530 \\
\hline & Mevzuatın sık s1k değişmesi &, 506 \\
\hline & Sorumlulukların endişe yaratması (sorumlulukların ağırlığı) & ,492 \\
\hline \multirow{5}{*}{$\begin{array}{l}\text { 5: İşin } \\
\text { Niteliği }\end{array}$} & Oda tarifesindeki ücretlerin yetersizliği & ,706 \\
\hline & Yapılan isin monoton ve değişime kapalı olması & ,639 \\
\hline & Beklenen işlerin çok kısa bir sürede yapılmasının zorunluluğu &, 589 \\
\hline & Gelirin az olması & 459 \\
\hline & Mevzuatın karmaşık olması & 426 \\
\hline
\end{tabular}




\begin{tabular}{|l|l|c|}
\hline \multirow{2}{*}{$\begin{array}{l}\text { 6: Mesleğin } \\
\text { Devamlılığ1 }\end{array}$} & Kalifiye meslek elemanı bulamama &, 782 \\
\cline { 2 - 3 } & Meslektaşların bilgi paylaşımındaki isteksizliği &, 687 \\
\hline \multirow{2}{*}{$\begin{array}{l}\text { 7: Bilgi } \\
\text { Düzeyi }\end{array}$} & Alınan mesleki eğitimin yetersizliği &, 723 \\
\cline { 2 - 3 } & Değişen muhasebe yazılımlarına uyum sağlayamama &, 551 \\
\cline { 2 - 3 } & Kendini işin gereklerine göre yetersiz görme &, 533 \\
\hline \multirow{2}{*}{ 8: Etik } & Mesleki etik kuralları ile mükellefin etiğe aykırı istekleri arasında kalma &, 755 \\
\cline { 2 - 3 } & Meslekteki değişme ve gelişmeleri izleyememek &, 639 \\
\hline
\end{tabular}

Faktör analizi öncesinde 33 olan değişken sayısı analiz sonrası 8'e indirgenmiştir. Analiz ayrıca her faktör için skorlar oluşturulmasını sağlamıştır. Oluşan bu skorların en büyük avantajı ise normal dağılım şartlarını sağlıyor olmaları ve çoklu bağlantı problemi taşımıyor olmalarıdır (Kalaycı 2014, 331). Elde edilen faktör skorları birer değişken olarak parametrik testlerde kullanılabilirler.

\subsection{Demografik Özelliklerle Strese Neden Olan Faktörlerin İlişkisi}

Çalışmanın bu bölümünde elde edilen faktörlerin demografik özelliklere göre farklılık gösterip göstermediği araştırılmıştır. İki kategorili demografik değişkenler için "Bağımsız İki Örneklem tTesti” kullanılmıştır. Bu test bağımsız iki örneklem ortalamaları arasındaki farkın istatistiksel olarak anlamlı olup olmadığını sınamak amacıyla geliştirilmiştir (Bayram 2014, 94). Üç veya daha fazla kategoriye sahip demografik değişkenlerin ölçümünde "One-Way ANOVA" testinden faydalanılmıştır.

Öncelikle katılımcıların mesleki stres faktörlerinden etkilenme düzeylerinin medeni durumlarına göre farklılık gösterip göstermediği belirlenmeye çalış1lmıştır. Yapılan test sonucunda anlamlı çıkan “Zaman” ve "Mesleğin Devamlılığı” faktörleri için sonuçlar Tablo 6'da görülmektedir.

Tablo 6. Medeni Duruma Göre t-Testi

\begin{tabular}{|c|l|l|l|l|l|}
\hline \multirow{2}{*}{$\begin{array}{c}\text { Faktör } \\
\text { No }\end{array}$} & \multicolumn{2}{|c|}{ Levene Testi } & \multicolumn{2}{c|}{ t-Testi } & \multirow{2}{*}{ Ortalama } \\
\cline { 2 - 5 } & \multicolumn{2}{|c|}{ Sig. } & \multicolumn{2}{|c|}{ t } & \\
\hline \multirow{2}{*}{4} & \multirow{2}{*}{1,968} & \multirow{2}{*}{, 162} & 1,974 &, 049 & 0,0741 (Evli) \\
\cline { 3 - 6 } & \multirow{2}{*}{6} & \multirow{2}{*}{, 950} & 2,801 &, 075 & $-0,2038$ (Bekâr) \\
\cline { 4 - 6 } & & & 2,308 &, 019 & 0,0883 (Evli) \\
\hline
\end{tabular}

Tablo 6'daki F değeri varyansların homojen olup olmadığını test etmek için kullanılır. Hemen yanındaki sütunda yer alan Sig. değerinin 0,05 'ten küçük olması varyansların homojen olmadığ anlamına gelmektedir. Fakat bu örnekte olduğu gibi Sig. değerinin 0,05 ’ten büyük olması varyansların homojen olduğunu gösterir. $\mathrm{p}$ değeri ise gruplar arasında fark olup olmadığını gösteren değerdir. Bu değer 0,05 'ten küçükse gruplar arasında fark olduğuna karar verilir. Eğer bu değer 0,05'ten büyükse karşılaştırılan gruplar arasında anlamlı fark olmadığına karar verilir. 
Sonuç olarak "Zaman" ve "Mesleğin Devamlılığı" faktörlerinin evli meslek mensuplarında daha fazla strese sebep olduğu da görülmektedir.

Katılımcıların stres faktörlerinden etkilenme seviyelerinin yaşlarına, eğitim durumlarına, ünvanlarına, çalışma şekillerine, mesleki tecrübelerine ve gelir seviyelerine göre farkl1l1k gösterip göstermediğini belirlemek amacıyla One-Way ANOVA testi yapılmıştır.

Eğitim durumu demografik değişkeni için anlamlı farklılık çıkan faktörler ile ilgili bilgiler Tablo 7'de görülmektedir.

Tablo 7. Eğitim Durumu İçin ANOVA Testi

\begin{tabular}{|c|c|c|c|c|c|c|c|c|c|}
\hline \multirow{3}{*}{ Değişken } & \multirow{3}{*}{ Faktör } & \multirow{2}{*}{\multicolumn{2}{|c|}{$\begin{array}{c}\text { Homogeneity } \\
\text { Levene Test }\end{array}$}} & \multirow{2}{*}{\multicolumn{2}{|c|}{ ANOVA }} & \multicolumn{4}{|c|}{ Multiple Comparisons (Post-Hoc) } \\
\hline & & & & & & \multirow{2}{*}{$\begin{array}{c}\text { Kategori } \\
\text { (1) }\end{array}$} & \multirow{2}{*}{$\begin{array}{c}\text { Kategori } \\
\text { (2) }\end{array}$} & \multicolumn{2}{|c|}{ Tukey } \\
\hline & & Stat. & $\mathbf{p}$ & $\mathbf{F}$ & Sig. & & & Mean Dif. & Sig. \\
\hline \multirow{24}{*}{$\begin{array}{l}\text { Eğitim } \\
\text { Durumu }\end{array}$} & \multirow{12}{*}{2} & \multirow{12}{*}{1,060} & \multirow{12}{*}{,367 } & \multirow{12}{*}{4,797} & \multirow{12}{*}{, $003 *$} & \multirow{3}{*}{ Lise } & Ön Lisans & , 1086 & ,996 \\
\hline & & & & & & & Lisans &,- 4026 & ,753 \\
\hline & & & & & & & Lisansüstü & $-1,1367$ & ,075 \\
\hline & & & & & & \multirow{3}{*}{ Ön Lisans } & Lise &,- 1086 & ,996 \\
\hline & & & & & & & Lisans &,- 5113 & ,184 \\
\hline & & & & & & & Lisansüstü & $-1,2453^{*}$ & ,002 \\
\hline & & & & & & \multirow{3}{*}{ Lisans } & Lise & ,4026 & ,753 \\
\hline & & & & & & & Ön Lisans &, 5113 &, 184 \\
\hline & & & & & & & Lisansüstü &,$- 7340^{*}$ & ,021 \\
\hline & & & & & & \multirow{3}{*}{ Lisansüstü } & Lise & 1,1367 & ,075 \\
\hline & & & & & & & Ön Lisans & $1,2453^{*}$ & ,002 \\
\hline & & & & & & & Lisans & ,7340* & ,021 \\
\hline & \multirow{12}{*}{6} & \multirow{12}{*}{ 333 } & \multirow{12}{*}{,801 } & \multirow{12}{*}{2,961} & \multirow{12}{*}{,033 } & \multirow{3}{*}{ Lise } & Ön Lisans & ,0434 & 1,000 \\
\hline & & & & & & & Lisans & ,6892 & ,334 \\
\hline & & & & & & & Lisansüstü & ,6758 & ,483 \\
\hline & & & & & & \multirow{3}{*}{ Ön Lisans } & Lise &,- 0434 & 1,000 \\
\hline & & & & & & & Lisans & ,6458 & ,059 \\
\hline & & & & & & & Lisansüstü & ,6324 & ,271 \\
\hline & & & & & & \multirow{3}{*}{ Lisans } & Lise &,- 6892 & ,334 \\
\hline & & & & & & & Ön Lisans &,- 6458 & ,059 \\
\hline & & & & & & & Lisansüstü &,- 0134 & 1,000 \\
\hline & & & & & & \multirow{3}{*}{ Lisansüstü } & Lise &,- 6758 & 483 \\
\hline & & & & & & & Ön Lisans &,- 6324 & 271 \\
\hline & & & & & & & Lisans & ,01340 & 1,000 \\
\hline
\end{tabular}

$(* 0,05)$

Tablo 7'de katılımcıların stres faktörlerinden 2'nci faktör olan maddi kaygılar ve 6'ncı faktör olan mesleğin devamlılığı etkilenme düzeyleri açısından eğitim durumlarına göre anlamlı farklılık olduğu görülmektedir. Bu faktörlerin Levene testi sonuçlarına bakıldığı zaman varyans homojenliği şartını sağladığı $(p>0,05)$ ve ANOVA sütununda faktörlere ait $F$ ve Sigma değerleri $(p<0,05)$ görülmektedir. 
Daha sonraki aşamada hangi ortalamaların birbirinden farklı olduğu araştırılmıştır. Bunun belirlenmesi için Post-Hoc testlerine başvurulmuştur. Tablo 7'nin Multiple Comparisons sütununda ANOVA testi sonucunda anlamlı bulunan demografik değişkenlerin her birinin alt kategorileri görülmektedir.

Çalışma şekli demografik değişkeni için anlamlı farklılık çıkan faktörler ile ilgili bilgiler Tablo 8 'de görülmektedir.

Tablo 8. Çalışma Şekli İçin ANOVA Testi

\begin{tabular}{|c|c|c|c|c|c|c|c|c|c|}
\hline \multirow{3}{*}{ Değişken } & \multirow{3}{*}{ Faktör } & \multirow{2}{*}{\multicolumn{2}{|c|}{$\begin{array}{c}\text { Homogeneity } \\
\text { Levene Test } \\
\end{array}$}} & \multirow{2}{*}{\multicolumn{2}{|c|}{ ANOVA }} & \multicolumn{4}{|c|}{ Multiple Comparisons (Post-Hoc) } \\
\hline & & & & & & \multirow{2}{*}{$\begin{array}{l}\text { Kategori } \\
\text { (1) }\end{array}$} & \multirow{2}{*}{ Kategori (2) } & \multicolumn{2}{|c|}{ Tukey } \\
\hline & & Stat. & p & $\mathbf{F}$ & Sig. & & & Mean Dif. & Sig. \\
\hline \multirow{18}{*}{$\begin{array}{l}\text { Çalışma } \\
\text { Şekli }\end{array}$} & \multirow{6}{*}{1} & \multirow{6}{*}{1,356} & \multirow{6}{*}{,260 } & \multirow{6}{*}{19,520} & \multirow{6}{*}{, 000} & \multirow{2}{*}{ Bağımsız } & Kamu-Özel & $-1,0919^{*}$ & ,000 \\
\hline & & & & & & & SMMM Yanı &,- 2650 & ,107 \\
\hline & & & & & & \multirow{2}{*}{$\begin{array}{c}\text { Kamu- } \\
\text { Özel }\end{array}$} & Bağımsız & $1,0919^{*}$ &, 000 \\
\hline & & & & & & & SMMM Yanı & ,8268* & ,000 \\
\hline & & & & & & \multirow{2}{*}{$\begin{array}{l}\text { SMMM } \\
\text { Yanı }\end{array}$} & Bağımsız & 2650 & ,107 \\
\hline & & & & & & & Kamu-Özel &,$- 8268^{*}$ & 000 \\
\hline & \multirow{6}{*}{2} & \multirow{6}{*}{2,973} & \multirow{6}{*}{,053 } & \multirow{6}{*}{10,454} & \multirow{6}{*}{, 000} & \multirow{2}{*}{ Bağımsız } & Kamu-Özel & ,7974* & ,000 \\
\hline & & & & & & & SMMM Yanı & ,3205* & ,047 \\
\hline & & & & & & \multirow{2}{*}{$\begin{array}{c}\text { Kamu- } \\
\text { Özel }\end{array}$} & Bağımsız &,$- 7974 *$ & ,000 \\
\hline & & & & & & & SMMM Yanı &,$- 4768 *$ & 037 \\
\hline & & & & & & \multirow{2}{*}{$\begin{array}{c}\text { SMMM } \\
\text { Yanı }\end{array}$} & Bağımsız &,$- 3205^{*}$ & ,047 \\
\hline & & & & & & & Kamu-Özel & ,4768* & ,037 \\
\hline & \multirow{6}{*}{7} & \multirow{6}{*}{,016 } & \multirow{6}{*}{,984 } & \multirow{6}{*}{5,979} & \multirow{6}{*}{,003 } & \multirow{2}{*}{ Bağımsız } & Kamu-Özel & ,2378 & ,399 \\
\hline & & & & & & & SMMM Yanı &,$- 3722 *$ & ,019 \\
\hline & & & & & & \multirow{2}{*}{$\begin{array}{c}\text { Kamu- } \\
\text { Özel }\end{array}$} & Bağımsız &,- 23787 & ,399 \\
\hline & & & & & & & SMMM Yanı &,$- 6100^{*}$ & ,006 \\
\hline & & & & & & \multirow{2}{*}{$\begin{array}{l}\text { SMMM } \\
\text { Yanı }\end{array}$} & Bağımsız & ,3722* & ,019 \\
\hline & & & & & & & Kamu-Özel & ,6100* & ,006 \\
\hline
\end{tabular}

$(* 0,05)$

Tablo 8'de katılımcıların stres faktörlerinden 1'inci faktör olan fiziki koşullar, 2'nci faktör olan maddi kaygılar ve 7'nci faktör olan bilgi düzeyi etkilenme düzeyleri açısından çalışma şekillerine göre anlamlı farklılık olduğu görülmektedir. Bu faktörlerin Levene testi sonuçlarına bakıldığı zaman varyans homojenliği şartını sağladığı $(\mathrm{p}>0,05)$ ve ANOVA sütununda faktörlere ait $\mathrm{F}$ ve Sigma değerleri $(\mathrm{p}<0,05)$ görülmektedir.

Daha sonraki aşamada hangi ortalamaların birbirinden farklı olduğu araştırılmıştır. Bunun belirlenmesi için Post-Hoc testlerine başvurulmuştur. Tablo 7'nin Multiple Comparisons sütununda ANOVA testi sonucunda anlamlı bulunan demografik değişkenlerin her birinin alt kategorileri görülmektedir.

Mesleki tecrübe demografik değişkeni için anlamlı farklılık çıkan faktörler ile ilgili bilgiler Tablo 9'da görülmektedir. 
Tablo 9. Mesleki Tecrübe İçin ANOVA Testi

\begin{tabular}{|c|c|c|c|c|c|c|c|c|c|}
\hline \multirow{3}{*}{ Değişken } & \multirow{3}{*}{ Faktör } & \multirow{2}{*}{\multicolumn{2}{|c|}{$\begin{array}{c}\text { Homogeneity } \\
\text { Levene Test }\end{array}$}} & \multirow{2}{*}{\multicolumn{2}{|c|}{ ANOVA }} & \multicolumn{4}{|c|}{ Multiple Comparisons (Post-Hoc) } \\
\hline & & & & & & \multirow{2}{*}{$\begin{array}{l}\text { Kategori } \\
\text { (1) }\end{array}$} & \multirow{2}{*}{ Kategori (2) } & \multicolumn{2}{|c|}{ Tukey } \\
\hline & & Stat. & $\mathbf{p}$ & $\mathbf{F}$ & Sig. & & & Mean Dif. & Sig. \\
\hline \multirow{20}{*}{$\begin{array}{l}\text { Mesleki } \\
\text { Tecrübe }\end{array}$} & \multirow{20}{*}{8} & \multirow{20}{*}{1,313} & \multirow{20}{*}{,265 } & \multirow{20}{*}{2,413} & \multirow{20}{*}{, 050} & \multirow{4}{*}{$\begin{array}{l}7 \text { Y1l ve } \\
\text { Alt1 }\end{array}$} & $8-15$ aras1 &,- 1470 & ,880 \\
\hline & & & & & & & $16-23$ aras1 & ,0324 & 1,000 \\
\hline & & & & & & & $24-31$ aras1 & ,4357 & 284 \\
\hline & & & & & & & 32 yıl ve üstü &,- 3929 & ,656 \\
\hline & & & & & & \multirow{4}{*}{$\begin{array}{l}8-15 \\
\text { Aras1 }\end{array}$} & 7 y1l ve alt1 &, 1470 & 880 \\
\hline & & & & & & & $16-23$ aras1 & ,1794 & 841 \\
\hline & & & & & & & 24-31 aras1 & ,5828 & ,051 \\
\hline & & & & & & & 32 yıl ve üstü &,- 2458 & ,908 \\
\hline & & & & & & \multirow{4}{*}{$\begin{array}{c}16-23 \\
\text { Aras1 }\end{array}$} & 7 y1l ve alt1 &,- 0324 & 1,000 \\
\hline & & & & & & & $8-15$ aras1 &,- 1794 & 841 \\
\hline & & & & & & & 24-31 aras1 & ,4033 & ,423 \\
\hline & & & & & & & 32 yıl ve üstü &,- 4253 & ,616 \\
\hline & & & & & & \multirow{4}{*}{$\begin{array}{c}24-31 \\
\text { Aras1 }\end{array}$} & 7 y1l ve alt1 &,- 4357 & 284 \\
\hline & & & & & & & $8-15$ arası &,- 5828 & ,051 \\
\hline & & & & & & & $16-23$ aras1 &,- 4033 & 423 \\
\hline & & & & & & & 32 yıl ve üstü &,- 8286 & ,081 \\
\hline & & & & & & \multirow{4}{*}{$\begin{array}{l}32 \text { Yil ve } \\
\text { Üstü }\end{array}$} & 7 y1l ve alt1 & ,39295 & ,656 \\
\hline & & & & & & & $8-15$ aras1 & ,2458 & ,908 \\
\hline & & & & & & & $16-23$ aras 1 & ,4253 & ,616 \\
\hline & & & & & & & $24-31$ aras1 & ,8286 & ,081 \\
\hline
\end{tabular}

$(* 0,05)$

Tablo 9'da katılımcıların stres faktörlerinden 8'inci faktör olan etikten etkilenme düzeylerinin mesleki tecrübelerine göre anlamlı farklılık olduğu görülmektedir. Bu faktörlerin Levene testi sonuçlarına bakıldığı zaman varyans homojenliği şartını sağladığı $(\mathrm{p}>0,05)$ ve ANOVA sütununda faktörlere ait F ve Sigma değerleri $(\mathrm{p}<0,05)$ görülmektedir.

Daha sonraki aşamada hangi ortalamaların birbirinden farklı olduğu araştırılmıştır. Bunun belirlenmesi için Post-Hoc testlerine başvurulmuştur. Tablo 7'nin Multiple Comparisons sütununda ANOVA testi sonucunda anlamlı bulunan demografik değişkenlerin her birinin alt kategorileri görülmektedir.

Gelir düzeyi demografik değişkeni için anlamlı farklılık çıkan faktörler ile ilgili bilgiler Tablo 10 'da görülmektedir. 
Tablo 10. Gelir Seviyesi İçin ANOVA Testi

\begin{tabular}{|c|c|c|c|c|c|c|c|c|c|}
\hline \multirow{3}{*}{ Değişken } & \multirow{3}{*}{ Faktör } & \multirow{2}{*}{\multicolumn{2}{|c|}{$\begin{array}{r}\text { Homogeneity } \\
\text { Levene Test }\end{array}$}} & \multirow{2}{*}{\multicolumn{2}{|c|}{ ANOVA }} & \multicolumn{4}{|c|}{ Multiple Comparisons (Post-Hoc) } \\
\hline & & & & & & \multirow{2}{*}{$\begin{array}{l}\text { Kategori } \\
\text { (1) }\end{array}$} & \multirow[b]{2}{*}{ Kategori (2) } & \multicolumn{2}{|c|}{ Tukey } \\
\hline & & Stat. & $\mathbf{p}$ & $\mathbf{F}$ & Sig. & & & $\begin{array}{l}\text { Mean } \\
\text { Dif. }\end{array}$ & Sig. \\
\hline \multirow{44}{*}{$\begin{array}{c}\text { Gelir } \\
\text { Düzeyi (‡) }\end{array}$} & \multirow{30}{*}{3} & \multirow{30}{*}{1,810} & \multirow{30}{*}{, 111} & \multirow{30}{*}{4,015} & \multirow{30}{*}{, 002} & \multirow{5}{*}{$\begin{array}{c}1500 \text { ve } \\
\text { Altı }\end{array}$} & $1501-2500$ aras 1 & ,4665 &, 316 \\
\hline & & & & & & & $2501-3500$ aras1 &,- 2023 & ,953 \\
\hline & & & & & & & $3501-4500$ aras 1 & 2914 & ,878 \\
\hline & & & & & & & $4501-5500$ aras1 & ,2483 & ,960 \\
\hline & & & & & & & 5501 üstü &,- 1236 & ,995 \\
\hline & & & & & & & 1500 alt1 &,- 4665 & ,316 \\
\hline & & & & & & & $2501-3500$ aras1 &,$- 6688^{*}$ &, 002 \\
\hline & & & & & & $1501-$ & $3501-4500$ aras1 &,- 1751 & ,963 \\
\hline & & & & & & & $4501-5500$ aras1 &,- 2181 & ,954 \\
\hline & & & & & & & 5501 üstü &,$- 5902 *$ & ,012 \\
\hline & & & & & & & 1500 alt1 & ,2023 & 953 \\
\hline & & & & & & & $1501-2500$ aras 1 & ,6688* & ,002 \\
\hline & & & & & & $2501-$ & $3501-4500$ aras1 & ,4937 & ,215 \\
\hline & & & & & & & $4501-5500$ aras 1 & ,4506 & ,497 \\
\hline & & & & & & & 5501 üstü & 0786 & ,998 \\
\hline & & & & & & & 1500 alt1 &,- 2914 & ,878 \\
\hline & & & & & & & $1501-2500$ aras 1 & ,1751 & ,963 \\
\hline & & & & & & $\begin{array}{c}5001- \\
4500 \text { Aras1 }\end{array}$ & $2501-3500$ aras1 &,- 4937 &, 215 \\
\hline & & & & & & & $4501-5500$ aras 1 &,- 0430 & 1,000 \\
\hline & & & & & & & 5501 üstü &,- 4150 & ,416 \\
\hline & & & & & & & 1500 alt1 &,- 2483 & ,960 \\
\hline & & & & & & & $1501-2500$ aras1 & ,2181 & ,954 \\
\hline & & & & & & $\begin{array}{l}4001- \\
5500 \text { Aras1 }\end{array}$ & $2501-3500$ aras1 &,- 4506 & ,497 \\
\hline & & & & & & & $3501-4500$ aras1 &, 0430 & 1,000 \\
\hline & & & & & & & 5501 üstü &,- 3720 & ,703 \\
\hline & & & & & & & 1500 alt1 & ,1236 & ,995 \\
\hline & & & & & & 5501 ve & $1501-2500$ aras1 &, $5902 *$ & ,012 \\
\hline & & & & & & Sö ve & $2501-3500$ aras1 &,- 0786 & ,998 \\
\hline & & & & & & & $3501-4500$ aras 1 & ,4150 & ,416 \\
\hline & & & & & & & $4501-5500$ aras 1 & ,3720 & 703 \\
\hline & & & & & & & $1501-2500$ aras1 &,- 1562 & ,983 \\
\hline & & & & & & & 2501-3500 aras1 &,- 1766 & ,973 \\
\hline & & & & & & $1500 \mathrm{ve}$ & $3501-4500$ aras 1 & ,2884 & ,879 \\
\hline & & & & & & & $4501-5500$ aras1 & 0723 & 1,000 \\
\hline & & & & & & & 5501 üstü & ,5670 & , 148 \\
\hline & & & & & & & 1500 alt1 & 1562 & ,983 \\
\hline & 7 & & & 4759 & & & $2501-3500$ aras1 &,- 0203 & 1,000 \\
\hline & 1 & , & נינד, & 4,132 &, 000 & $2500 \Delta \mathrm{rag}$ & $3501-4500$ aras 1 & ,4447 & ,289 \\
\hline & & & & & & & $4501-5500$ aras 1 & ,2286 & ,943 \\
\hline & & & & & & & 5501 üstü & ,7233* &, 001 \\
\hline & & & & & & & 1500 alt1 & ,1766 & ,973 \\
\hline & & & & & & $2501-$ & $1501-2500$ aras 1 & 0203 & 1,000 \\
\hline & & & & & & 3500 Aras1 & $3501-4500$ aras1 & ,4650 & ,269 \\
\hline & & & & & & & $4501-5500$ aras 1 & ,2489 & ,925 \\
\hline
\end{tabular}




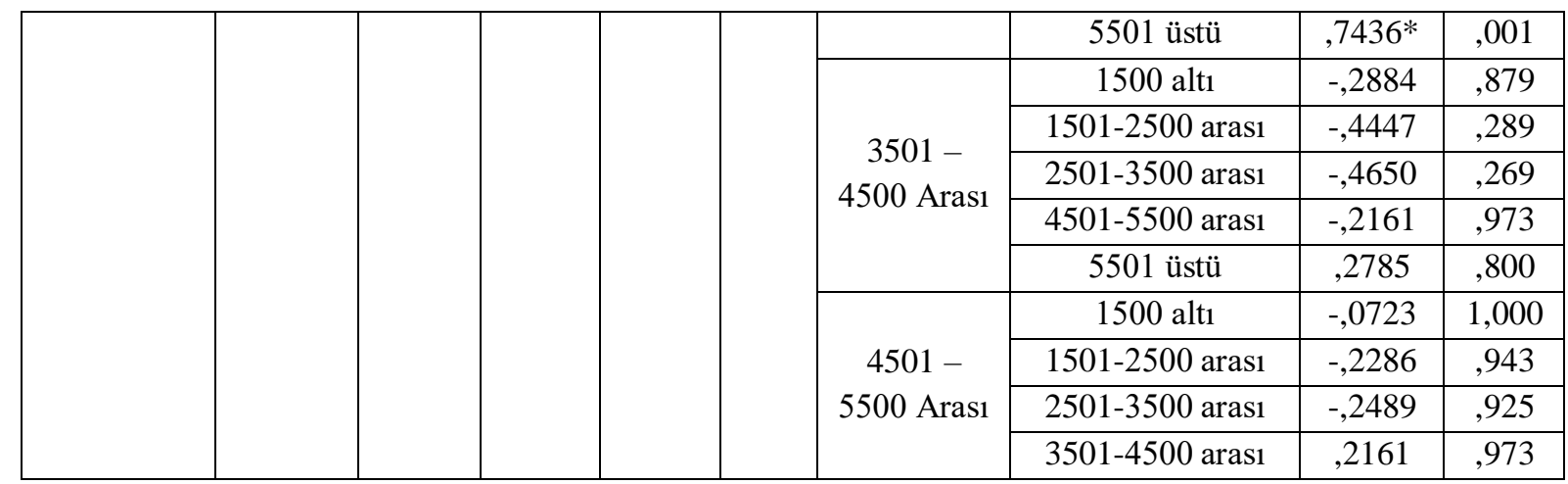

$(* 0,05)$

Tablo 10'da katılımcıların stres faktörlerinden 3'üncü faktör olan standartlar ve denetim, 7'inci faktör olan bilgi düzeyinden etkilenme düzeylerinin mesleki tecrübelerine göre anlamlı farklılık olduğu görülmektedir. Bu faktörlerin Levene testi sonuçlarına bakıldığı zaman varyans homojenliği şartını sağladığı $(p>0,05)$ ve ANOVA sütununda faktörlere ait $F$ ve Sigma değerleri $(p<0,05)$ görülmektedir.

Daha sonraki aşamada hangi ortalamaların birbirinden farklı olduğu araştırılmıştır. Bunun belirlenmesi için Post-Hoc testlerine başvurmuştur. Tablo 7'nin Multiple Comparisons sütununda ANOVA testi sonucunda anlamlı bulunan demografik değişkenlerin her birinin alt kategorileri görülmektedir.

\section{SONUÇ}

Stres, iş hayatının kaçınılmaz gerçeklerinden biridir. Muhasebe mesleği, doğası gereği iş hayatında oldukça geniş bir kesimi ilgilendirmekte ve stres, muhasebe mesleği mensuplarının da sıklıkla mücadele ettikleri bir olgu haline gelmektedir.

$\mathrm{Bu}$ çalışma; Kayseri'deki muhasebe meslek mensuplarında strese neden olan mesleki faktörleri açıklayabilmek ve bu faktörlerin demografik değişkenlere göre farklılık gösterip göstermediğini ortaya koyabilmek amacıyla yapılmıştır. Bu amaç doğrultusunda hazırlanan anket formu 255 muhasebe meslek mensubuna yüzyüze görüşme yöntemiyle uygulanmıştır. Anketin birinci bölümü katılımcıların demografik özelliklerini ölçen 8 sorudan, ikinci bölümü ise katılımcıların mesleki stres unsurlarından etkilenme derecelerini ölçen 34 önermeden oluşmaktadır. Stres unsurlarını ölçen 34 önermenin belirlenmesinde konu ile ilgili literatürden faydalanılmıştır.

Çalışmanın daha sonraki aşamasında 34 önermenin daha az sayıda değişkene indirgenip indirgenemeyeceğinin belirlenmesi için faktör analizi yapılmış ve katılımcıların görüşülenin 8 faktörle $\% 63,112$ oranında açıklanabileceği belirlenmiştir. Bu durumda meslek mensuplarının etkilendiği 
mesleki stres faktörleri; fiziki koşullar, maddi kaygılar, standartlar ve denetim, zaman, işin niteliği, mesleğin devamlılı̆̆

Bunun ardından, belirlenen faktörlerden katılımcıların etkilenme seviyelerinin demografik değişkenlere göre farklılık gösterip göstermediğinin belirlenebilmesi amaciyla t-testi ve tek yönlü varyans analizi (ANOVA) yapılmıştır.

İlk olarak "Zaman" ve "Mesleğin Devamlılı̆̆ı" faktörlerinin evli meslek mensuplarında daha fazla strese sebep olduğu sonucuna ulaşılmıştır.

Ayrıca önlisans ve lisansüstü mezuniyete sahip katılımcıların maddi kaygılar faktöründen etkilenme seviyeleri arasında istatistiki açıdan anlamlı bir farklılık olduğu belirlenmiştir.

Çalışma şekillerine göre mesleki stres faktörlerinden etkilenme seviyeleri incelendiği zaman ise elde edilen sonuçlar aşağıdaki gibidir;

- Bağımsız çalışan meslek mensupları ile kamu - özel sektörde çalışan meslek mensupları ve SMM yanında çalışan ile kamu - özel sektörde çalışan meslek mensuplarının fiziki koşullar stres faktöründen etkilenme seviyeleri arasında istatistiki açından anlamlı bir farklılık bulunmaktadır.

- Bağımsız, kamu - özel sektörde ve SMM yanında çalışan meslek mensuplarının maddi kaygılar stres faktöründen etkilenme seviyeleri arasında istatistiki açından anlamlı bir farklılık bulunmaktadır.

- Bağımsız çalışan meslek mensupları ile SMM yanında çalışan meslek mensupları ve kamu özel sektörde çalışan meslek mensupları ile SMM yanında çalışan meslek mensuplarının bilgi düzeyi stres faktöründen etkilenme seviyeleri arasında istatistiki açıdan anlamlı bir farklılık bulunmaktadır.

Çalışanların gelir düzeylerine göre stres faktörlerinde etkilenme seviyeleri arasında ise aşağıdaki sonuçlara ulaşılmıştır;

- $\quad 1501$ - 2500 arası ile 2501 - 3500 arası ve 1501 - 2500 ile 5501 ve üzeri aylık gelire sahip meslek mensuplarının standartlar ve denetim stres faktöründen etkilenme seviyeleri arasında istatistiki açından anlamlı bir farklılık bulunmaktadır.

- $\quad 2501$ - 3500 ile 5501 ve üzeri aylık gelire sahip meslek mensuplarının bilgi düzeyi stres faktöründen etkilenme seviyeleri arasında istatistiki açından anlamlı bir farklılık bulunmaktadır.

Muhasebe meslek mensuplarının mesleki stres unsurlarından etkilenme seviyelerini belirlemeyi amaçlayan ve Kayseri İli'nde yapılmış bu çalışmaya benzer nitelikteki akademik çalışmalar, diğer illerdeki meslek mensuplarına da uygulanabilir ve elde edilen sonuçların iller bazında karşılaştırılabilir. 
Çalışmanın Türkiye genelinde yapılması ile meslek mensuplarının daha az stresle çalışma hayatlarına devam etmelerine imkân sağlanabilecektir. Nitekim çalışan bireylerin ve örgütlerin başarılı olmalarında, stresin neden olabileceği olumsuz etkilerin elimine edilmesi son derece önemli görülmektedir.

\section{KAYNAKÇA}

Alpar, R. 2017. Uygulamalı Çok Değişkenli İstatistiksel Yöntemler (5. Baskı), Detay Yayıncılık, Ankara.

Aşık, N. 2005. "Otel İşletmelerinde İşgörenlerin Örgütsel Stres Kaynakları ve Stresin Bireysel Sonuçlarına İlişkin Bir Araştırma", Mevzuat Dergisi, 91.

Bayram, N. 2014. Sosyal Bilimlerde SPSS ile Veri Analizi (4. Bask1), Ezgi Kitabevi, Bursa.

Bekçi, İ., V. Ömürbek, ve Ö. Tekşen. 2007. "Muhasebe Meslek Mensuplarında Stres Kaynağının Belirlenmesine Yönelik Bir Araştırma", Süleyman Demirel Üniversitesi İktisadi ve İdari Bilimler Fakültesi Dergisi, 12(1).

Bulgurcu Gürel, E. 2016. "Duygusal Tükenmişlik, İş Stresi ve İşe Bağl1lığın İş-Aile Çatışması Üzerindeki Etkisi: Ampirik Bir Araştırma”, Dumlupınar Üniversitesi Sosyal Bilimler Dergisi, 48.

Cengiz, E. ve B. Özden. 2002. "Perakendecilikte Büyük Alışveriş Merkezleri ve Tüketicilerin Büyük Alışveriş Merkezleri ile İlgili Tutumlarını Tespit Etmeye Yönelik Bir Araştırma”, Ege Akademik Bakış, 2(1).

Eren Gümüştekin, G. ve A. Bircan Öztemiz. 2004. "Örgütsel Stres Yönetimi ve Uçucu Personel Üzerinde Bir Araştırma”, Erciyes Üniversitesi İktisadi ve İdari Bilimler Fakültesi Dergisi, 23.

Gök, S. 2009. "Çalışma Yaşamının Önemli Bir Sorunu: Örgütsel Stres”, Marmara Üniversitesi İktisadi ve İdari Bilimler Dergisi, 27(2).

Güney, S. ve H. Akdağ. 2018. "Tükenmişlik Sendromunun Muhasebe Meslek Mensupları Açısından İncelenmesi (Erzincan ve Erzurum İllerinde Bir Araştırma)", Atatürk Üniversitesi İktisadi ve İdari Bilimler Dergisi, 32 (2).

Henson, R.K. ve R.J. Kyle. 2006. "Use of Exploratory Factor Analysis in Published Research: Common Errors and Some Comment on Improved Practice", Educational and Psychological Measurement, 66(3).

Kalaycı, Ş. 2014. SPSS Uygulamalı Çok Değişkenli İstatistiksel Teknikler (6.Baskı), Asil Yayın Dağıtım, Ankara. 
Kaplanoğlu, E. 2014. "Mesleki Stresin Temel Nedenleri ve Muhtemel Sonuçları: Manisa İlindeki SMMM'ler Üzerine Bir Araştırma", Muhasebe ve Finansman Dergisi, 64.

Kayıhan, B., Y. Tepeli, B. Heybeli ve H. Bakan. 2015. "Muhasebe Meslek Mensuplarında Strese Neden olan Faktörlerle İş Tatmin Düzeyi arasındaki İlişkinin Analizi: Muğla Örneği’”, Akademik Sosyal Araştırmalar Dergisi, 3(14).

Kelly, T. and M. Barrett. 2011. "The Leading Causes and Potential Consequences of Occupational Stress: A study of Irısh Trainee Accountants", Irish Accounting Review, 18(2).

Özmutaf, N.M. ve R. Mizrahi. 2017. "SMMM ve Diğer Muhasebe Çalışanları Kapsamında, İş Stresinin İş Performansına Etkisi: İzmir İlinde Bir Araştırma", Süleyman Demirel Üniversitesi Vizyoner Dergisi, 8(18).

Shin, Y-J. and S-N. Lee. 2015. "The Impact of Emotional Labor and Job Stress on the Job Burnout in the Digital Era: Focusing on Staff Accountants", Journal of Digital Convergence, 13(2).

Tepeli, Y., B. Heybeli ve B. Kayıhan. 2014. "Muhasebe Meslek Mensuplarında Strese Neden Olan Faktörlerin Belirlenmesi Üzerine Bir Araştırma: Muğla İli Örneği", Uluslararası Sosyal Araştırmalar Dergisi, 7(35).

Williams, B., A. Onsman and T. Brown. 2010. "Exploratory in Factor Analysis: A Five - Step Guide For Novices", Journal of Emergency Primary Health Care, 8(3).

Yanık, A. 2017. "Muhasebe Meslek Mensuplarının Algıladıkları Stres Düzeyine Yönelik Bir Araştırma", Uluslararası Ekonomik Araştırmalar Dergisi, 3(1).

Yousefi, S., S. Nayebzadeh, and H. Eslami. 2015. "The Effects of Job stress on Accountants Job Satisfaction", Iran Occupational Health, 12(3).

Zeytin, M. ve A. Gökgöz. 2011. "Muhasebe Meslek Mensuplarında Strese Neden Olan Faktörlerin İncelenmesi: Yalova ve Bilecik İlleri Örneği”, Gümüşhane Üniversitesi Sosyal Bilimler Elektronik Dergisi, 3. 